\title{
Om e-lærebøger på iPad
}

\section{Jens Jørgen Hansen}

Adjunkt

Institut for Design og Kommunikation,

Syddansk Universitet.

\section{Lars Johnsen}

\section{Lektor}

Institut for Design og Kommunikation,

Syddansk Universitet.
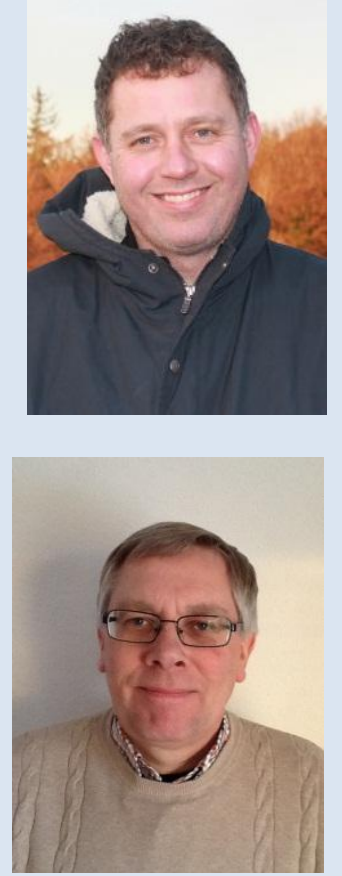

\section{Abstract}

I denne artikel introduceres e-lærebøger til iPad, og mere specifikt iBooks. Artiklen beskriver e-lærebogens potentiale som (mobilt) digitalt læremiddel på videregående uddannelsesniveau og sammenligner den med andre former for indholdsbaserede læremidler, herunder materialer på cd-rom og web. Endvidere illustreres iBooks' anvendelsesmuligheder gennem et konkret tænkt eksempel inden for det humanistiske område. 


\section{Introduktion}

Inden for hele uddannelsesområdet, herunder de videregående uddannelser, har der i et stykke tid været en støt stigende interesse for udvikling og anvendelse af digitale læringsressourcer til mobile platforme som smartphones og tablets (tavlecomputere). Interessen har nok især været centreret om de pædagogiske og didaktiske muligheder, der ligger i de såkaldte apps, dvs. mindre softwareapplikationer typisk udviklet med et specifikt formål for øje. Eksempler på sådanne apps er forskellige former for skrivestøtteværktøjer, billed- og videoredigeringsapplikationer, præsentations- og kommunikationsværktøjer og så videre.

Men med den stadigt større udbredelse af tablets som Apples iPad og Samsung Galaxy Tab er også mere indholdsbaserede læringsressourcer kommet i fokus. Det gælder eksempelvis e-bogen, som kan ses som en naturlig afløser for den traditionelle lærebog, som har haft en central plads i megen af den undervisning, som er foregået på universiteter, professionshøjskoler og andre videregående uddannelsesinstitutioner.

I denne artikel introducerer vi e-lærebøger til iPads, eksemplificeret ved de såkaldte iBooks, og diskuterer og illustrerer blandt andet sådanne digitale læremidlers muligheder for at fremme en mere aktiv og engagerende læring end (e-)bøger måske har gjort indtil nu. Især betoner vi det didaktiske potentiale, der ligger i at kombinere en traditionel lineær tekst til "dybdelæsning" med interaktivt, multimodalt læringsindhold, som den studerende på egen hånd kan udforske, afprøve eller eksperimentere med og på den måde "åbne døre" ind til bogens faglige univers. iBooks og lignende e-lærebøger åbner så at sige en ny scene for formidling af fagligt indhold og for iscenesættelse af læreprocesser. Den studerendes traditionelle rolle som "læser" og "opgaveløser" kan med iBooks udvides til også at være "eksperimentator", "konstruktør" og "projektdeltager".

Artiklen diskuterer hvilke brugspotentialer, der generelt karakteriserer elærebøger og mere specifikt iBooks. Den tager afsæt i det synspunkt, at iBooks kan beskrives som ressourcer, der har tre brugspotentialer affordances: det teknologiske (hvad kan teknologien?), det 
aktivitetsmæssige (hvad kan brugeren gøre?) og det pædagogiske (hvilke undervisningsmæssige opgaver og problemstillinger kan teknologien hjælpe til at løse?).

I artiklen anskues e-lærebøger som digitale medier til distribution af semiotiske ressourcer, således som dette begreb defineres og anvendes i socialsemiotikken af f.eks. van Leeuwen:

"Semiotic resources are the actions, materials and artifacts we use for communicative purposes, whether produced physiologically - for example, with our vocal apparatus, the muscles we use to make facial expressions and gestures - or technologically - for example, with pen and ink, or computer hardware and software - together with the ways in which these resources can be organized. Semiotic resources have a meaning potential, based on their past uses, and a set of affordances based on their possible uses, and these will be actualized in concrete social contexts where their use is subject to some form of semiotic regime" (van Leeuwen, 2005, p. 285).

Perspektivet i denne artikel er med andre ord medieteknologisk i den forstand, at det primære fokus er på e-lærebogen som digitalt medium for betydningsskabelse i pædagogisk/didaktisk kommunikation generelt og mere snævert i, hvad man kunne kalde (mobil) faglig formidling. En egentlig læringsteoretisk analyse af e-lærebogen som pædagogisk redskab ligger således ikke inden for denne artikels rammer.

\section{E-bogen og den trykte bog}

E-bogen som materiale har en række oplagte fordele frem for den trykte bog. Den er enkel og billig at producere og nem at distribuere: Den skal ikke vejen igennem forlag, bogtrykker og boghandel. En e-bog er i bund og grund blot en eller flere (pakkede) elektroniske filer, der kan konverteres fra et tekstbehandlingsprogram, uploades til en webserver og derefter downloades og læses på en hardware-enhed som en computer, en smartphone eller en dedikeret e-bogslæser som eksempelvis en Kindle. Det betyder igen, at e-bøger løbende kan opdateres, og nye versioner publiceres. Ikke mindst i forskningsbaseret undervisning kan dette siges at 
være en fordel: nye forskningsresultater og referencer og links til aktuelle artikler eller konferenceindlæg kan hurtigt indarbejdes i e-lærebogen og dermed sikre de studerende den nyeste viden.

E-bøger er solide. De bliver ikke bøjede eller falder fra hinanden. De er gode for miljøet, kræver minimalt med plads og vejer (næsten) intet. Ebøger kan derfor siges at være mere fleksible end den trykte bog: for den sprogstuderende f.eks. er det således intet problem at have romaner, ordbøger og litteraturhistorie i tasken eller rygsækken samtidig, og det kræver normalt kun et par klik eller tastetryk at bevæge sig fra den ene bog til den anden i det elektroniske "bogskab". Elektroniske bøger kan endvidere udstyres med funktionalitet, som traditionelle trykte bøger af gode grunde ikke har. Layout, typografi og lyssætning kan læseren normalt selv vælge, og søgninger i teksten kan foretages elektronisk. Sidst, men ikke mindst kan e-bøger være multimodale og interaktive. De kan indeholde tekst, billeder, videoklip, interaktive øvelser og "gå på Nettet".

Man kan mene, at e-bøger er en dårlig erstatning for den "ægte vare". Den manglende materialitet gør, at man som læser ikke har "føling" med, og overblik over, bogen og dens omfang, størrelse og indhold. Disse mangler er især udtalte, når e-bogen læses på en smartphone med dens diminutive skærm. Men på en tablet som iPad synes problemet mindre. Skærmen er større; man kan "bladre" frem og tilbage i bogen med fingrene, og selve hardware-enheden er fysisk på størrelse med en bog. Eller sagt på en anden måde: en iPad ligner mere en bog, end en mobiltelefon eller bærbar computer gør.

E-bøger findes i forskellige formater, nogle åbne og standardiserede, andre lukkede og proprietære. iBooks-formatet er for eksempel Apples eget lukkede format, mens EPUB er et ofte anvendt åbent format til e-bøger. Nogle er begrænsede til bestemte software- eller hardwareplatforme, mens andre kan læses på forskellige medier. E-bøger i iBooks-formatet er således bundet til iPad'en og kan - indtil videre - ikke afvikles på andre platforme, ikke en gang på Apples egne produkter som iPhone. 
Der findes efterhånden en række programmer til udvikling, administration og/eller visning af e-bøger, hvoraf nogle er open source og gratis. Det gælder således Calibre (http://calibre-ebook.com/). Med Calibre kan man eksempelvis konvertere sine Word-dokumenter til EPUB, tilføje metadata til dem og få dem vist som e-bøger på sin computerskærm.

E-bøger indgår i stadig stigende grad i sammenhængende læringsmiljøer eller -økosystemer. På Connexions (http://cnx.org), som er et amerikansk Web 2.0-site til produktion, deling og distribution af åbne læringsressourcer, kan såvel selvstændige læringsmoduler som hele kurser ikke blot tilgås som almindelige websider via en browser, men også downloades som e-bøger i EPUB-format og læses på en mobil enhed (se f.eks. Dohn \& Johnsen, 2009).

\section{iBooks}

Som allerede nævnt er iBooks et godt eksempel på e-lærebøger, der distribueres på en mobil platform som iPad. iBooks designes, udvikles og publiceres ved hjælp af iBooks Author, et Mac-baseret forfatterværktøj, der gratis kan downloades fra Apples App-store. Terminologien kan her være lidt forvirrende, da appen iBooks ikke blot kan fremvise e-bøger i iBooksformatet, men også e-bøger i EPUB-format og endog filer i PDF-format. iBooks kan distribueres frit, hvis de er gratis, men kun gennem Apples Appstore, hvis de skal afsættes i kommercielt øjemed, noget der naturligt nok har affødt en del kritik på diverse uddannelsesblogs.

iBooks - og iBooks Author - bruger eksplicit den fysiske bog som metafor. En iBook består således typisk af kapitler, sektioner og sider og kan udstyres med klassiske strukturelementer som indholdsfortegnelse og krydsreferencer. Endvidere åbner iBooks op for, at læseren kan indsætte bogmærker og noter og på baggrund af disse noter oprette såkaldte læsekort, som kan studeres separat. Forfatterværktøjet indeholder desuden en række funktioner til fastsættelse af typografi og layout, indsættelse af billeder, video og hypertekstlinks, oprettelse af glossar til definition af faglige begreber, m.v. 
Mest interessant i en pædagogisk og didaktisk sammenhæng er nok muligheden for at skabe interaktivitet - dialog, kontrol og manipulation (se nedenfor) - gennem indsættelse af såkaldte widgets, små programmer med et bestemt formål og en afgrænset funktionalitet. iBooks Author indeholder en grafisk grænseflade til at designe og indsætte en håndfuld foruddefinerede widget-typer. Det gælder f.eks. interaktive billeder, billedgallerier og multiple choice-øvelser. Men ønsker man selv at integrere egne widgets, kan dette også lade sig gøre, idet iBooks (Author) understøtter HTML5, det nyeste webformat, og dertilhørende teknologier som grafikformatet SVG og programmeringssproget JavaScript. Med HTML5-baserede widgets kan man eksempelvis udvikle interaktive øvelser, der sikrer en udbygget og/eller differentieret feedback til brugeren, eller man kan oprette små apps, der dynamisk henter relevante data fra Nettet. Det kan være videoer fra YouTube, billeder fra Flickr eller tweets fra Twitter. For den almindelige underviser er den umiddelbare udfordring med sådanne widgets selvfølgelig, at de skal kodes og/eller programmeres fra grunden. Men også her synes der hjælp på vej, idet der på nettet er ved at dukke websites op, hvor man kan få hjælp til udvikling af widgets uden selv at være programmør. Et eksempel er sitet Bookry (http://bookry.com/), hvorfra man allerede nu kan downloade widgets til visning af YouTube-videoer, Google Maps eller interaktive tidslinier i iBooks. (Problemet ved sådanne sites kan så til gengæld være nogle andre: manglende kvalitet og sikkerhed, betalingsforhold og -vilkår osv.).

Læsningen af en iBook på en iPad kan foregå på to måder: enten ved at iPad'en "stilles på højkant" (portrait) eller ved, at enheden "lægges ned" (landscape). Positionen spiller en rolle for den måde bogens tekst og øvrige indhold vises på. Med iPad'en på højkant vises teksten i en lang "rulle", der kan "scrolles" med fingrene, mens teksten kan bladres side for side, når iPad'en er lagt ned. Billeder, kort, videoer og andre indsatte multimodale objekter præsenteres også forskelligt alt efter, hvordan læsningen foregår. I portrait-visning er disse vist og placeret som små ikoner uden for teksten, mens de i landscape-visning præsenteres i naturlig størrelse og optræder inde i selve teksten som en integreret del af denne. Lagt ned fylder en side hele skærmen på iPad'en. Sider kan dog "knibes sammen" og placeres på et 
rullebånd nederst på siden med små ikoner, der hver især repræsenterer en side. Vi ser med andre ord, at platform og materiale interagerer: den fysiske brug af platformen har betydning for den måde, materialet formidles og tilgås på. Denne forskel i præsentation kan udnyttes didaktisk og bruges til at understøtte forskellige former for læringsaktiviteter. iBook'en kan således både læses som en fortløbende lineær tekst (portrait) og arbejdes med som en interaktiv multimedieapplikation (landscape). Den kan på én og samme tid udfolde og forklare begreber og sammenhænge i det faglige stof og aktivere, udfordre og engagere læseren.

\section{E-lærebøger, CD-ROM og websites}

E-lærebogen deler karakteristika med andre indholdsbaserede digitale læremidler så som websites og materialer på cd-rom. Disse kan også gøres multimodale, interaktive, indeholde links til andre ressourcer på nettet osv. Så hvorfor overhovedet begynde at interessere sig for tablet-baserede elærebøger som iBooks i forbindelse med læring og undervisning på de videregående uddannelser. Vi mener, der kan være flere grunde. For det første er iBooks mere "taktile" end cd-rom- og webbaserede ressourcer, der tilgås og manipuleres indirekte, typisk via tastatur og mus. Med en iBook er læseren i direkte kontakt med sit indhold, der kan bladres, rulles, knibes sammen og foldes ud med fingrene. E-lærebogen er fysisk engagerende, om man vil. For det andet hviler e-lærebogen på en meget lang kulturtradition og bruger eksplicit metaforik om indhold, grænseflade og funktionalitet, som enhver lærende kender og er fortrolig med (sider, kapitler, bogmærker, etc.). Det sænker konceptuelle barrierer og gør læringskurven mindre stejl for førstegangsbrugeren. For det tredje læses e-lærebøger altid gennem en applikation, en "e-reader", der for den enkelte lærende normalt vil være den samme over en længere periode. Dette giver e-lærebogen den samme grænseflade og det samme "look and feel" på tværs af typer og genrer og betyder, at når først den lærende en gang har lært applikationens grænseflade og funktionalitet at kende, indebærer tilgangen til, og brugen af, e-lærebogens indhold ikke yderligere komplikationer. Dette gælder ikke på samme måde cdrom-baserede materialer eller websites, der meget ofte indeholder designelementer, der er unikke for det enkelte materiale eller site. 
Navigationsdesign er det oplagte eksempel: navigationsmenuer placeres, layoutes og formateres forskelligt, nogle gange kan de foldes ud, andre gange ikke; links kan åbnes som pop-up dialogbokse, på en ny fane eller i et nyt vindue o.s.v. Faktisk opfattes et unikt design nogle gange netop som det, der skal gøre materialet eller sitet interessant, spændende eller "innovativt". For det fjerde, og dette er måske det vigtigste, har e-lærebogen typisk fokus på noget andet end cd-rom-materialer og websites, nemlig det tekstlige. E-bøger er normalt tekst - plus noget mere. På websites og i cd-rom-materialer er det ofte omvendt: her er der naturligvis også tekst, men tekstmængden er reduceret og ofte skåret til i "synoptiske" moduler, der ikke fylder mere end skærmen, mens andre modaliteter som billeder og grafik gives større prominens. Dette ideal om mindre tekst reflekteres i mange tilgange til webkommunikation. Det er således ikke tilfældigt, at en aktuel lærebog om webwriting har titlen: "Letting Go of the Words. Writing Web Content that Works" (Reddish, 2012). Men tekst som kompleks kommunikationsform er stadig helt central, når det gælder faglig formidling på videregående niveau: her er der behov for konceptualisering, forklaring, eksemplificering, elaborering og sammenvævning af emner og temaer. Alt dette kan teksten, ikke mindst pga. dens inhærente dialogiske og diskursive struktur: Tekst er på en og samme tid en imaginær dialog mellem forfatter og læser, hvor hver ny sætning kan siges at repræsentere et svar elller en respons på et hypotetisk spørgsmål eller en opfordring fra læseren, og et informationsflow, hvor begreber, ideer og udsagn kontinuerligt introduceres, udfoldes og kvalificeres og kædes sammen med nye ditto (Renkema, 2009). Med e-lærebogen sættes teksten igen i centrum, så at sige, nu blot i en digital ramme med de muligheder, det giver.

\section{E-lærebogen - en ny type it-applikation?}

Dalsgaard (2011) identificerer på grundlag af bl.a. Koschmann (1996) tre traditioner inden for udvikling af it-applikationer og digitale læringsressourcer. Den første tradition udviklet i 60'erne er Instructional Design-traditionen. Denne tradition er inspireret af en behavioristisk og kognitivistisk læringsforståelse, hvor et fagligt indhold struktureres i en videnspakke som indholds- og vidensobjekter. Læringsindholdet 
repræsenterer her fundamentale principper og begreber inden for et fag. Computeren fungerer her som en underviser, der formidler det faglige indhold og gennem den lærendes øvelser giver feedback på den lærendes læringsaktiviteter.

Den anden tradition opstår i 80'erne og er en konstruktionistisk tradition. En central person i denne tradition er Seymour Papert og hans arbejde med konceptet "Logo-as-Latin", som er en slags "discovery-based learning", hvor den lærende arbejder med selv at konstruere mikroverdener og computerbaserede simulationer. Teknologien får her en ny rolle. I stedet for at være lærerens stand-in bliver den et redskab for den lærende til selv at programmere, designe og konstruere.

Den tredje tradition kan beskrives som en socialkonstruktivistisk tradition med CSCL (Computer Supported Collaborative Learning) som det centrale omdrejningspunkt. Traditionen tager udgangspunkt i, at læring er en social aktivitet ikke kun en individuel kognitiv aktivitet. Særlig i fokus er endvidere den lærendes brug af redskaber til at tilegne sig og bearbejde informationer samt samarbejde og kommunikere med andre:

\section{Læring handler ikke længere om at få del i information, men om at kunne gøre erfaringer i miljøer, hvor fysiske og intellektuelle redskaber stilles til rådighed på en for individet rimelig måde, og hvor de bruges på at indhente information på den ene side, og gøre erfaringer på, som muliggør tilegnelse af begrebssystemer og færdigheder, på den anden. (Säljö, 2001, p. 258)}

Teknologiens rolle er her at tilbyde redskaber til indhentning af information, kommunikation, samarbejde og fælles konstruktion med mail, konferencesystemer og diskussionsfora som de dominerende teknologier (Dalsgaard, 2011, p. 173).

En e-lærebog har umiddelbart mange fællestræk med it-applikationer inden for en instructional design-tradition. Lærebogen er kendetegnet ved en række undervisende funktioner, som er iscenesat af lærebogens forfatter med den intention at sætte en læreproces i gang, støtte forståelse 
og brug af faglig viden i praksis. De centrale undervisende funktioner i den traditionelle trykte lærebog beskriver Hacker (1980) som en struktureringsfunktion (strukturere indhold), en repræsentationsfunktion (repræsentere indhold), en styringsfunktion (understøtte lærerens metodiske håndtering af undervisningen), en motivationsfunktion (motivere eleverne eller de studerende i deres læreproces), en differentieringsfunktion (støtte lærerens arbejde med at differentiere undervisningen) og en øvelses- og kontrolfunktion (støtte læreren i at få feedback om resultat og progression i elevens eller den studerendes læreprocesser). Lærebogens grundlæggende funktion er således, at den både formidler fagets indhold, iscenesætter læringsaktiviteter og vejleder læreren i at planlægge, gennemføre og evaluere undervisning. E-lærebogen kan siges at rumme de samme undervisende funktioner, men den tilbyder også yderligere funktioner, der tilgodeser et konstruktionistisk og socialkonstruktivistisk læringssyn. F.eks. kan den støtte den lærendes arbejde med at designe, konstruere, afprøve og korrigere. Og den kan mediere kommunikative samarbejdsrelationer mellem lærende. Her indgår e-lærebogen i en socialkonstruktivistisk tradition. Det skal imidlertid understreges, at de forskellige aktiviteter - læsning, kommunikation, konstruktion, samarbejde mv. alle kan foregå med afsæt i selve bogens indhold.

\section{E-lærebogens brugspotentiale}

Et digitalt læremiddels, og dermed en e-lærebogs, brugspotentiale - dets affordances - siger noget om dets egenskaber og muligheder for brug. Brug omfatter både perception og handling (Gaver, 1991). Et digitalt læremiddels brugspotentiale kan man anskue fra tre perspektiver: dets teknologiske egenskaber og funktionalitet, dets aktivitetsmæssige muligheder og dets pædagogiske formål (Hansen, 2010).

\section{Teknologisk brugspotentiale}

Det teknologiske brugspotentiale realiseres af funktionalitet på tre niveauer: indholds-, applikations-, og platformsniveau. På indholdsniveau findes funktionalitet, der er knyttet til selve den multimodale teksts indhold, f.eks. interaktive billeder, kort eller øvelser. På applikationsniveau realiseres 
brugspotentialet af den generiske software, som bogen åbnes i og læses med. Denne software kan stille funktionalitet til rådighed i form af søgefunktioner eller funktioner til at tage noter, sætte bogmærker eller lignende. Endelig tilbyder selve hardware-platformen et brugspotentiale. For eksempel giver en mobil platform som iPad mulighed for at udnytte lokationsbaserede tjenester og integrere disse direkte i e-lærebogen. Den mobile platform kan endvidere åbne nye læringsrum og situerede læringssituationer, som ikke er begrænset af det traditionelle klasserum. Man kan her tale om læremidlets bærbarhed (Fibiger, 2010) og dermed også den lærendes og læringskontekstens mobile potentiale.

\section{Aktivitetsmassigt brugspotentiale}

For den studerende skal et læremiddel ses i relation til en læreproces. Et generelt bud på en læreproces er, at den omfatter tre prototypiske aktiviteter: interaktion med et fagligt stof, bearbejdning af et fagligt stof og produktion og kommunikation af forståelsen af det faglige stof i et læringsudtryk. Den studerendes interaktion med et fagligt stof foregår gennem forskellige modaliteter eller udtryksformer: skrift, billede, lyd mv. (Kress \& van Leeuwen, 2001). Disse forskellige modaliteter har betydning for den studerendes forskellige måder at percipere det faglige stof på og kan aktivere forskellige sanser, f.eks. synssans, høresans og den taktile sans.

I forhold til den studerendes bearbejdning af det faglige stof muliggør den teknologiske funktionalitet, at den studerende kan interagere med det faglige stof på forskellig vis. Man kan her tale om forskellige interaktivitetsformer, dvs. forskellige måder hvorpå den studerende kan påvirke og kontrollere læremidlets indhold og/eller udtryk. Den interaktive dimension kan understøtte den studerendes aktive læreproces og tilegnelse af faglig viden og færdigheder.

Den interaktive dimension kan beskrives i tre centrale interaktionsformer: dialog, kontrol og manipulation (se f.eks. Moreno \& Mayer, 2007). Dialogisk interaktivitet består f.eks. i, at den studerende kan stille et spørgsmål og modtage et svar eller, at den studerende kan give et svar på et spørgsmål og modtage feedback fra læremidlet. Kontrollerende interaktivitet betyder, at den studerende bestemmer hastighed og/eller læsevej og navigation i et læringsforløb. Manipulerende interaktivitet indebærer, at den studerende 
kan kontrollere aspekter af præsentationen, så som at flytte objekter på et kort eller sætte parametre for en simulation, f.eks. sætte rentesatser i en lånesimulation eller bestemme en given nedbørsmængde i en klimasimulation.

Den lærendes kommunikation af læringsudtryk indebærer, at et læremiddel understøtter den studerendes kommunikation om sin forståelse. En sådan kommunikativ praksis er samtidig også en bearbejdning og i sig selv en læreproces. Den lærendes læringsudtryk kan f.eks. udtrykkes i genrer som notetagning, diskussion, test, fremlæggelser, mind-maps og opgaveskrivning. Et læremiddel har som grundlæggende funktion at mediere en lærendes proces i forhold til at opleve, forstå, bearbejde og kommunikere om sin forståelse. Læremidler hjælper den studerende til at håndtere en række opgaver i relation til hans eller hendes arbejds- og læreprocesser og understøtter på forskellig vis pågældendes kognitive kapacitet. Et læremiddel er sammenvævet med den måde, den lærende håndterer situationer, manipulerer processer, tilegner sig viden, forstår og forklarer verden og deltager i læringsaktiviteter på (Hansen, 2010). Som aktivitetsmæssigt potentiale i forhold til den studerendes læreprocesser kan man her tale om et læremiddels lærbarhed - dvs. det har en kvalitet til at støtte, strukturere og stabilisere den lærendes læreprocesser.

\section{Paedagogisk brugspotentiale}

Et læremiddel kan - alt efter dets design - noget, men det læremidlet kan, aktualiseres først, når det bliver brugt i en bestemt situation til et bestemt formål. Man kan på den ene side skelne mellem, hvordan et læremiddel støtter generelle pædagogiske formål - f.eks. lærerens realisering af klasserumsundervisning, et projektforløb eller en ekskursion på et museum og på den anden side, hvordan et læremiddel understøtter specifikke pædagogiske og faglige formål - f.eks. at stimulere danskstuderendes indsigt i Blichers litteratur, historiestuderendes forståelse af prærieindianernes kultur og levevis eller samfundsfagsstuderendes tilegnelse af evalueringsteori og -metoder.

Hvordan e-lærebogens brugspotentialer - især det teknologiske - kan realiseres ved hjælp af iBooks eksemplificeres i det følgende. 


\section{iBooks - og deres anvendelse}

Hvordan iBooks konkret - og mest hensigtsmæssigt - kan anvendes til læring, undervisning og uddannelse afhænger naturligvis i høj grad af hvilken type e-lærebog, man ønsker at udvikle, hvilket fag eller fagområde, den sigter mod, og i hvilke læringsscenarier, den påtænkes at skulle indgå. Man kan forestille sig, at en e-lærebog til sprogundervisning typisk vil indeholde mange interaktive, multimodale øvelser til træning af sproglige færdigheder, mens en e-fagbog i historie måske mest vil gøre brug af ikkedynamisk autentisk kildemateriale i form af indscannede dokumenter, billeder, kort, lydoptagelser og lignende. Omvendt vil et historisk emateriale måske gøre brug af iPad'ens indbyggede mulighed for at identificere brugerens aktuelle fysiske placering i forhold til historiske mindesmærker, artefakter eller udstillingsgenstande, mens dette sjældent vil være relevant for en elektronisk håndbog i grammatik.

Vi vil dog kort illustrere iBooks' anvendelsesmuligheder gennem et konkret tænkt eksempel inden for det humanistiske område, nemlig en e-bog om maleren Emil Nolde. Den faglige kontekst for udviklingen af e-bogen kunne være et valgfag om ekspressionisme på danskstudiet. Valgfaget handler om ekspressionisme i litteraturen, arkitekturen og i malerkunsten og heri indgår et forløb om den tyske ekspressionist Emil Nolde. Det faglige mål for forløbet er både kunsthistorisk (indsigt i den ekspressionistiske malerkunst) og biografisk (indsigt i Noldes liv som kunstner og som privatperson). Undervisningen foregår både som klasseundervisning og som en ekskursion til Nolde-museet i Seebüll lige syd for grænsen. Læreren har derfor brug for læremidler, der både præsenterer ekspressionisme i malerkunsten generelt, Nolde som ekspressionist og hans kunstneriske og biografiske udvikling samt engagerer og strukturer de studerendes læringsaktiviteter på ekskursionen til Nolde-museet. En e-bog kan her fungere som ressource for systematisk præsentation af det faglige stof i form af faglige artikler og eksempler, en ramme for aktivering af studerendes undersøgelser af det faglige stof i form af opgaver og øvelser samt som en mobil guide til de studerendes situerede læring på projekter og ekskursioner uden for klasserummet. 
En sådan e-bog kan kombinere en traditionel tekstuel fremstilling af Noldes liv, virke og rolle som kunstner og samfundsdebattør med en mere visuel og interaktiv præsentation af hans kunst, herunder hans motivvalg, formgivning og inspirationskilder. Formidlingen af sidstnævnte kan ske gennem interaktive billeder og billedgallerier. Eksempelvis kan hans kunstneriske udvikling fra overvejende impressionist til ekspressionist illustreres gennem et billedgalleri, der kan bladres igennem i kronologisk orden. Galleriet kan også være forsynet med en tidslinje og en manuel skyder, således at læseren kan fremfinde malerier, der er typiske for en bestemt tidsperiode, f.eks. "Nolde under nazismen". Mens billedgallerier kan vise tendenser og udviklinger og give overblik, kan interaktive billeder være med til at beskrive og forklare malerierne hver for sig. Ved at klikke på markerede områder eller objekter på billedet kan læseren blive præsenteret for en overlejret tekstuel beskrivelse i et pop-up vindue og herigennem få et empirisk baseret indblik i Noldes motiv- og farvevalg, hans brug af symboler, etc.

Multimodale objekter behøver ikke være indsat i selve e-bogen. Widgets kan åbne eksterne ressourcer i den. Det kan være en Wikipedia-artikel, der definerer fænomenet ekspressionisme, en YouTube-video med uddrag af en guided tour på Nolde-museet eller de fotos, der er lagt op på Web 2.0sitet Flickr og rubriceret under kategorien "Emil Nolde". E-lærebogen bliver derfor en slags Web 2.0-applikation i sig selv.

Og en iBook om Emil Nolde behøver ikke kun være formidlende. Den kan også være engagerende og aktiverende. Med muligheden for at indsætte noter og oprette læsekort kan den studerende selv dokumentere og føje til og på den måde i beskedent omfang blive medproducent af bogens indhold. Men man kan også forestille sig, at den indeholder mere praktiske eller kreative øvelser, hvor den studerende gennem HTML-widgets får til opgave at eksemplificere eller illustrere aspekter af kunstnerens arbejdsform og formgivning gennem udarbejdelse af skitser, farvelægning eller færdiggørelse af visuelle oplæg.

En iBook er mobil og anvendelig i forskellige læringsrum til forskellige læringsaktiviteter. En iBook om Emil Nolde kan være den centrale 
læringsressource i et forløb om ekspressionisme i dansk kunst og danne grundlag for dybdelæsning om ekspressionisme på et kollegieværelse, for en projektor-præsentation om Noldes tidlige akvareller i et klasseværelse og som audio-visuel guide på en ekskursion til Nolde-museet i Seebüll.

\section{E-lærebogen i forskellige læringsrum}

Undervisning og læring kan således i princippet finde sted alle steder. Man kan her skelne mellem formelle læringsrum, halvformelle læringsrum og uformelle læringsrum (Kahr-Højland, 2005). Formelle læringsrum findes inden for universitetets mure. De er karakteriseret ved, at de er konstrueret til at realisere undervisningens faglige målsætninger. Halvformelle rum har også fokus på vidensformidling, men ikke med udgangspunkt i konkrete faglige målsætninger. Biblioteker, museer og oplevelsescentre som Danfoss Universe og Experimentarium er eksempler på disse rum. Uformelle læringsrum kan være byens rum og naturens landskaber.

I en ekskursion til Nolde-museet åbnes således et halvformelt læringsrum. Museet som læringsrum er karakteriseret ved, at det formidler og udstiller Noldes kunst i museets gallerier. Endvidere formidler museet udstillinger og plancher om Noldes liv og virke samtidig med, at museets galleri tidligere har tjent som bolig for Nolde, hvorved oplevelsen af Noldes hus, have og marskens storslåede natur også giver et indtryk af kunstnerens inspirationskilder. Museets galleri kan i samspil med e-bogen sætte rammen for særlige læringsaktiviteter af både reciperende og undersøgende karakter. De studerende kan, når de står over for et konkret maleri, få anskueliggjort maleriets motiver, billedsproglige virkemidler og ekspressionistiske stiltræk. Det er en særlig læringssituation, hvor både et objekt (maleriet) og dets faglige præsentation (begreber og faglige diskurser om objektet) er til stede i samme fysiske rum. De studerende kan både se og opleve maleriet in real og samtidig få nuanceret multimodal information om objektets indhold og kontekst. E-bogen kan altså fungere som interaktiv guide under museumsbesøget. E-lærebogen kan også præsentere opgaver og iscenesætte undersøgelsesaktiviteter. De studerende kan blive bedt om at sammenligne malerier fra forskellige perioder og beskrive Noldes kunstneriske og billedsproglige udvikling og her bruge iBooks' indbyggede 
notetagningsfunktion. Eller de studerende kan gå på motivjagt og finde eksempler på gennemgående motiver og symboler i Noldes æstetiske univers.

\section{Afslutning}

iBooks har et stærkt brugspotentiale som et nyt format til digitale læremidler, der åbner nye muligheder for faglig og pædagogisk formidling samt nye veje for engagerende og interaktive læreprocesser. Det er en hovedpointe, at dette brugspotentiale kan sættes i spil af underviseren selv. En underviser har med forfatterværktøjet iBooks Author mulighed for selv at producere og distribuere egne materialer, herunder inkludere diverse interaktive læringsobjekter. Begrænsningerne er dog, som tidligere nævnt, dels at produktionen af iBooks kun kan foregå på en Mac, og afvikling kun kan ske på en iPad og ikke på andre tablets. Endvidere kan kommerciel distribution kun ske gennem Apples egen App-store.

Sammenfattende kan man sige, at e-lærebøger som iBooks åbner op for:

- multimodal formidling af et fagligt stof og

- dialogisk og diskursiv fremstilling af dette

- aktivering af engagerende interaktivitet hos den lærende

- fleksibel og situeret brug i differentierede læringsrum

- produktion af underviserens egne materialer

\section{Referencer}

Dalsgaard, C. (2011): Nye vidensmediers liv på nettet. I Nielsen, Høyrup og Christensen: Nye vidensmedier. Kultur, læring og kommunikation. Frederiksberg: Samfundslitteratur.

Dohn, N.B. \& Johnsen, L. (2009): E-læring på Web 2.0. Frederiksberg: Samfundslitteratur.

Fibiger, B. (2010): Mobile mediers læringspotentialer: didaktiske overvejelser i forbindelse med brugen af podcast og vodcast. Tidsskriftet Læring og medier (LOM), nr. 5. http://ojs.statsbiblioteket.dk/index.php/lom/article/view/3950

Gaver, W. (1991): Technology affordances. Proceedings of the CHI 1991. New York: ACM Press. 
Hacker, H. (1980). Didaktische Funktionen des Mediums Schulbuch. I Hacker, H. (red.): Das Schulbuch. Funktion und Verwendung im Unterricht. Bad Heilbrunn: Klinkhardt.

Hansen, J.J. (2010): Læremiddellandskabet. Fra læremiddel til undervisning. Akademisk Forlag.

Kahr-Højland, A. (2005): Interaktiv formidling af kroppen - en læringsmæssig resurse? Idrætshistorisk Årbog, Dansk Idrætshistorisk Forening - Krop og Kultur. Syddansk Universitetsforlag

Koschmann, T. (1996): Paradigm Shifts and Instructional Technology: An Introduction. I Koschmann, T. (red.): CSCL: Theory and Practice of an Emerging Paradigm. New Jersey: Lawrence Erlbaum Associates: 1-23.

Kress, G. \& Van Leeuwen, T. (2001). Multimodal Discourse. The Modes and Media of Contemporary Communication. London: Arnold.

Langer, M. (2012): iBooks Author: Publishing Your First Ebook. Maria's Guides.

Moreno, R. \& Mayer, R. (2007): Interactive Multimodal Learning Environments. Educ Psychol Rev. 19:309. Springer.

Pastore, M. (2008): 30 Benefits of Ebooks. http://epublishersweekly.blogspot.dk/2008/02/30-benefits-ofebooks.html

Redish, J. (2012): Letting Go of the Words. Writing Web Content that Works. Morgan Kaufmann. 2nd edition.

Renkema, J. (2009): The Texture of Discourse. Amsterdam/Philadelphia: John Benjamins Publishing Company.

Säljö, R. (2000): Læring i praksis. Et sociokulturelt perspektiv. København: Hans Reitzel

Van Leeuwen, T. (2005): Introducing Social Semiotics.London: Routledge

Wenger, E. (1998): Communities of Practice. New York: Cambridge University Press. 